\title{
Use of mannanoligosacharides as an adjuvant treatment for gastrointestinal diseases and this effects on E.coli inactivated in $\operatorname{dogs}^{1}$
}

\author{
Uso de mananoligossacarídeos fosforilados como adjuvante no tratamento de \\ doenças gastrointestinais e seu efeito na inativação da $E$. coli em cães
}

\author{
Eliana Maria FerreiraGouveia ${ }^{2}$, Iandara Schettert Silva ${ }^{3}$,Valter Joost Van Onselem ${ }^{4}$, Rui Alberto Caetano Corrêa ${ }^{4}$, \\ Camila Junqueira e Silva 5 . \\ 1. Postgraduate Program on Agroindustrial Production and Management Work of University for Development of the State and the \\ Pantanal Region (UNIDERP), Campo Grande, Brazil. \\ 2. Master, Fellow PhD degree in Postgraduate Program on Health and Development in West Central Region, Federal University of Mato \\ Grosso do Sul (UFMS), Campo Grande, Brazil. \\ 3. PhD, Associate Professor of Department of Veterinary, UNIDERP, Brazil. \\ 4. PhD, Department of Production, UFMS, Brazil. \\ 5. Fellow Master degree in Postgraduate Program on Agroindustrial Production and Management, UNIDERP, Brazil.
}

\begin{abstract}
Purpose: To evaluate the effects of mannanoligosacharides on dogs showing gastroenteritis. Methods: Sixteen dogs, 26 month-old, distributed into two groups: T1 - animals with gastroenteritis receiving treatment for the disease + mannanoligosacharides ( $2 \mathrm{~g}$ /animal); and T2 - animals with gastroenteritis receiving just treatment for the disease. The animals were randomly included in the sample and all of them were submitted to blood and feces collection for coproculture. In the treatment for gastroenteritis antibiotic, antihemetic, vermifuge, vitamins and sorotheraphy were used. The parameters evaluated were the numbers of leucocytes, neutrophils, lymphocytes and the presence of enteropathogenic bacteria in feces. Results: The mannanoligosacharides was effective in eliminating pathogenic E. coli in $85.71 \%$ of the animals, while in the no-treated group only $25 \%$ of the animals were negative to E. coli. Conclusion: The mannanoligosacharides is effective in the control of pathogenic $E$. coli and it can be indicated as an adjuvant treatment for gastroenteritis in dogs. Key words: Gastroenteritis. Escherichia coli. Probiotics. Dog Diseases.
\end{abstract}

\section{RESUMO}

Objetivo: Avaliar os efeitos da adição de mananoligossacarídeos fosforilados (MOS) que apresentavam gastroenterite , pacientes de uma Clínica Veterinária. Métodos: foram estudados 16 cães de 2 a 6 meses de idade, de várias raças. Os animais foram distribuídos em 2 grupos, sendo o grupo $\mathrm{T}_{1}$ composto por animais com gastroenterite, que receberam o tratamento para a doença e Mos (2,0 g/animal) e o grupo $\mathrm{T}_{2}$, animais com gastroenterite, que somente receberam o tratamento para a doença sem o MOS. Os animais foram incluídos aleatoriamente na amostra e todos eles foram submetidos à coleta de sangue e de fezes para coprocultura.O tratamento para a gastroenterite constituiu-se de antibiótico,antiemético,vermífugo,vitaminas e soroterapia. No experimento, foram avaliados os leucócitos, neutrófilos, linfócitos e a presença de bactérias enteropatogênicas nas fezes. Resultados: Constatou-se a efetividade do Mos no grupo tratado, quando houve a eliminação da Escherichia coli patogênica em $85,71 \%$ dos animais, enquanto que, no grupo sem o Mos, só $25 \%$, não apresentaram o microorganismo. Conclusão: O Mos é efetivo no controle da $E$. coli patogênica, sendo indicado como tratamento adjuvante nas gastroenterites.

Descritores: Gastroenterite. Escherichia coli. Probióticos. Doenças do Cão.

\section{Introduction}

There are several factors that can cause gastroenteritis including viral and bacterial infection, endoparasites and other agents, however the definitive diagnostic is not relevant once the treatment is only symptomatic. It is observed an increase in mortality of young animals when gastroenteritis occurs and when pathogenic bacteria are still present. Phosphorylated mannanoligosaccharides (MOS) are complex carbohydrates with mannose receptors that can bind pathogenic bacteria, eliminating available receptor sites, thus avoiding other bacteria from attaching to the epithelium. The microbial food additives, defined as sources of live microorganisms, include bacteria, fungi and yeasts. The most important and usually added to ruminant diets are the yeasts, yeast cultures and fungi extracts. The carbohydrates play several roles in the nutrition of dogs, cats and other companion animals. Three important functions of carbohydrates in biological systems used to be recognized - the first was to act as energy source or component for energy storage; the second was to act as a structural component like cellulose and chitin; and the third 
was confusing to scientists due to the diversity and complexity of these compounds. Nowadays, the carbohydrates and oligosaccharides have been used as nutritional modulators of the immune system. The carbohydrates are involved in all aspects of biological sciences. The wide range of possibilities available related to the structure and function of polysaccharides makes glycomics a science that study sugars and the structure of these sugars that are components of the cells. The phosphorylated mannanoligosaccharides are derived from a specific yeast strain (Sacharomyces cerevisiae strain 1026). These complex carbon hydrates are found mostly in the yeast cell wall, which is composed of more than $30 \%$ of mannanoligosaccharides. The cell wall is a complex matrix of protein and complex carbon hydrate that serves as a protective barrier around the cell and an interface between the cell and the extracellular surroundings. Thus, this complex matrix was developed with special characteristics to allow the communication with the extracellular surroundings. After analyzing the function of sugars in intracellular communication, it was demonstrated that the complex oligosaccharides such as the mannanoligosaccharides play fundamental roles in these interactions ${ }^{1}$. In many cases, bacterial infections occur due to the ability of the bacteria to recognize sugars present in the host cell surface and use specific receptors that allow them to attach, colonize, and, in the case of pathogens, cause disease in the animals. Mannose-specific lectins (protein fimbriae on the bacterial surface) are utilized by many gastrointestinal pathogens as a means of attachment to the gut epithelium ${ }^{2}$. The isolated definition of leavening mentions the product to it that was separate of the way of culture of leavenings: it is the composed product for leavend leavenings, that is, viable cells, with its half one of growth. Amongst the cultures of leavenings it is distinguished, particularly, of Saccharomyces cerevisae. The neutrophils are destroyed in the inflammatory focus, when eat the bacterium (or other agents). Still in this initial acute phase of the inflammation, the lymphocytes frequently are diminished, had to a hormone release ${ }^{3}$. The action way, according to the authors, is based on the capacity of linking of MOS the a specific Gran-negative microbes through its interaction with sensible lactinas to manose present in the surface of these bacteria. The commercial application of this phenomenon was demonstrated by the capacity of ME to reduce the counting of Salmonella in chickens inoculated with a culture of these microrganismos ${ }^{4}$. The prebióticos (ME) modulate the gastrointestinal motilidade, reduce the diarréia (increased water absorption), promote the development of the mucosa of the íleo and of cólon, they provide energy to the intestinal mucosa, diminish $\mathrm{pH}$ of cólon favoring the one growth microbiota beneficial, increase the protection against infections (function of the barrier, immunity), among others effect ${ }^{5}$. Research with ME has been lead has five years more than and, in this short period of time, advances with regard to the briefing in its way of action had been gotten front to promotional antibiotics of growth (APCs). This factor is, in part, responsible for the degree of existing indetermination and confusion how much to the impossibility to reintroduce the use of APCs in the ration. More than 100 published assays of research had demonstrated to the benefits of ME for the health and the performance of swines, birds and vitelos. ME also it was tested successfully in other species, such as rabbits, ostriches, emas and fish. The improvement index, as much with ME as with the APCs, depended on diverse factors that incluíam the sanitary state of the birds, the degree of contamination of the way for the illness, the level of estresse and the age of the animal ${ }^{6}$. The briefing of the effect of continues ME, especially, in relation to its effect on the imunitário system. Diverse researchers had described interesting comments in swines, vitelos and birds, being that other works lead in this area will be able to provide excellent information on ME in the next years, especially with regard to the enterite ${ }^{6}$. They had carried through experiments, supplementing dogs with 2, $0 \mathrm{~g}$ ME, 2, $0 \mathrm{~g}$ of FOS or 2,0g ME $+2,0 \mathrm{~g}$ of FOS per day, during 14 days, dogs supplemented with $2,0 \mathrm{~g}$ of FOS $+2,0 \mathrm{~g}$ ME per day had presented expressivo increase in the concentrations of IgA in the íleo in relation the dog-control, also indicating stimulaton of the local immunity. The dogs supplemented with ME had presented a lesser concentration of aeróbicas bacteria and a trend of rise of the concentrations of lactobacilos in excrements ${ }^{7,8}$. This trial aimed to evaluate the effect of MOS in animals with viral, parasitic or bacterial gastroenteritis with or without blood, and also to determine bacterial presence and alterations in feces, and changes in the number of leucocytes and neutrophils.

\section{Methods}

A total of 16 dogs (Rottweiler, Pit Bull, Poodle and nopedigree) from 2 to 6 months old suffering from gastroenteritis were used in the study. The animals were kept in individual cages for 10 days. The sick animals received sorotheraphy and were treated for the disease. These animals, selected according to the age, had gastroenteritis and diarrhea with or without blood. Because MOS was provided orally, animals showing vomit were not used in the study. The animals were submitted to blood collection (2,0 $\mathrm{ml}$ of blood) punched from cephalic vein, stored in sterilized flasks with anticoagulant (EDTA) and conserved at temperatures between 2 and 8 ÚC. Feces were collected with sterile swabs $(1.0 \mathrm{~g})$ with mucus, pus or blood and stored in environmental temperature for coproculture analyses on the $1 U^{\prime}, 5 U^{\prime}$ and $10 U^{\prime}$ days, considering the $1^{\text {st }}$, $2^{\text {nd }}$ and $3^{\text {rd }}$ collection, respectively. The samples were sent to Pardini Laboratory in Minas Gerais, Brazil. Animals with gastroenteritis were examined to evaluate the level of dehydration. Through the determination of the dehydration rate, the fluid therapy treatment was started until hydration, followed by the maintenance treatment with Ringer lactate and physiological solution at $0,9 \%$. The animals were distributed into two groups: T1 - animals with gastroenteritis receiving treatment for the disease + Bio-Mos; and T2 animals with gastroenteritis receiving treatment for the disease, without Bio-Mos. In the treatment for gastroenteritis antibiotic, antihemetic, vermifuge, vitamins and sorotheraphy were used. The antibiotic treatment consisted of intravenous enrofloxacin $(5 \mathrm{mg} / \mathrm{Kg})$ during 3 or 4 days, diluted in equal parts during two minutes. The antihemetic used was metoclopramide chloridrate (1-2mg/ 
$\mathrm{kg})$ total volume, administrated during 24 hours. The vermifuges used were Praziquantel, Pyrantel Pamoate (10mg/ $\mathrm{kg}$ ) administered orally when animals were not vomiting. Vitamins $B_{1}$ and $B_{12}$ were also used. In the beginning of the study, animals were fed easily digestible diets once intestine takes one or two weeks to regenerate. In the group fed diets containing MOS, $2 \mathrm{~g}$ of medication diluted in $2,0 \mathrm{ml}$ of water were provided orally to animals that were not eating. The effects of treatments were evaluated upon three variables obtained through hemogram (total leukocytes, segmented neutrophils and lymphocytes) and a variable obtained from coproculture (presence or absence of $E$. coli). The data were collected in the $1^{\text {st }}, 5^{\text {th }}$ and $10^{\text {th }}$ days of internment and the alterations occurred in the number of total leukocytes,

\section{Results}

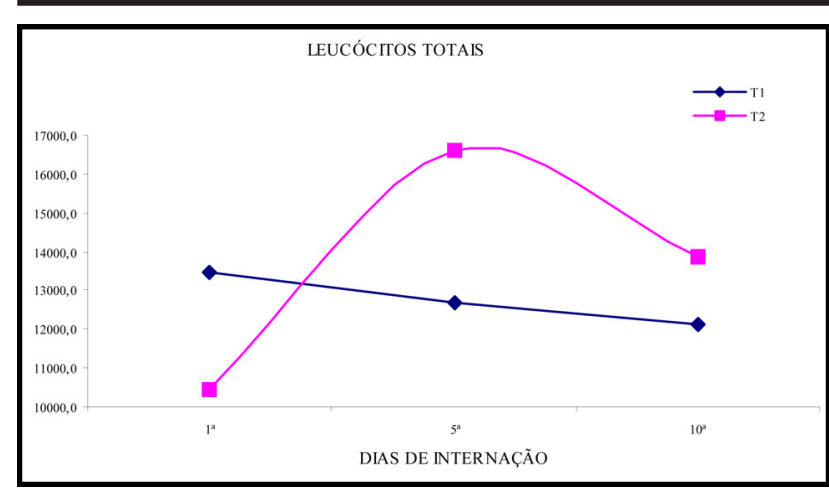

FIGURE 1 - Number of total leukocytes obtained in the hemogram of dogs from T1 (with MOS) and $\mathrm{T} 2$ (without MOS) in the $1^{\text {st }}, 5^{\text {th }}$ and $10^{\text {th }}$ days.

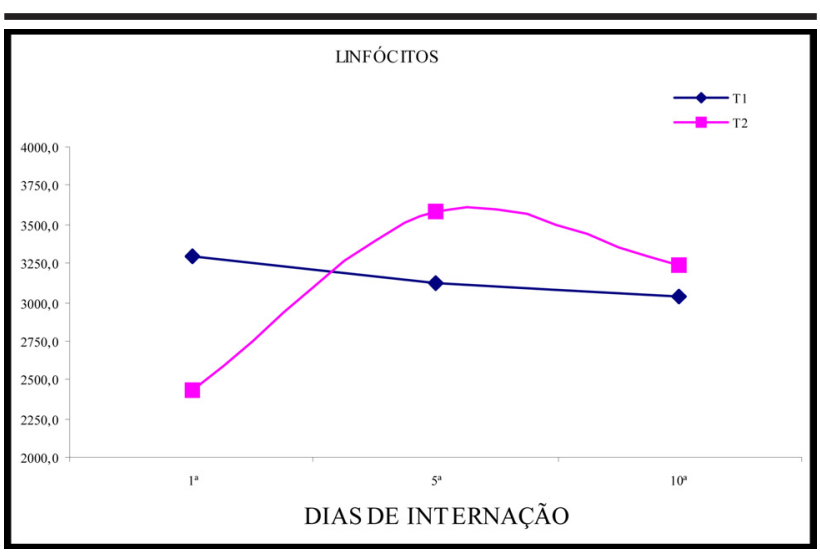

FIGURE 3 - Number of lymphocytes obtained in the hemogram of dogs from T1 (with MOS) and $\mathrm{T} 2$ (without MOS) in the $1^{\text {st }}, 5^{\text {th }}$ and $10^{\text {th }}$ days.

\section{Discussion}

There were no statistically differences between the two groups with respect to leukocytes analysis. These data remained on physiological parameters, what can be considered as a clinical improvement (Figure 1). In a bacterial infection, due to the inflammatory process, the number of segmented neutrophils and lymphocytes between the $1^{\text {st }}$ and $5^{\text {th }}, 5^{\text {th }}$ and $10^{\text {th }}$ and $1^{\text {st }}$ and $10^{\text {th }}$ days were observed. A completely randomized experimental design was used. The first dog showing gastroenteritis received treatment with MOS (T1), the second one received treatment without MOS (T2) and then successively. As samples of the two groups were independent and total leukocytes, segmented neutrophils and lymphocytes can be evaluated in the ordinal measurement scale, Mann-Whitney $U$ test was used to compare the groups with and without MOS. Exact Fisher test was used in the $10^{\text {th }}$ day of the experimental period to determine the effect of MOS on the frequency of dogs that stopped being positive to $E$. coli. P-values higher than 0.05 were not considered statistically significant.

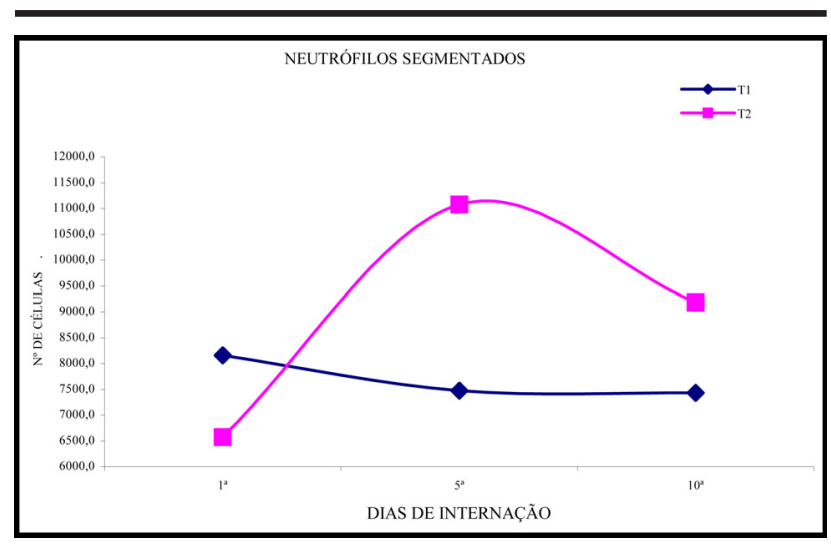

FIGURE 2 - Number of segmented neutrophils obtained in the hemogram of dogs from T1 (with MOS) and T2 (without MOS) in the $1^{\text {st }}, 5^{\text {th }}$ and $10^{\text {th }}$ days.

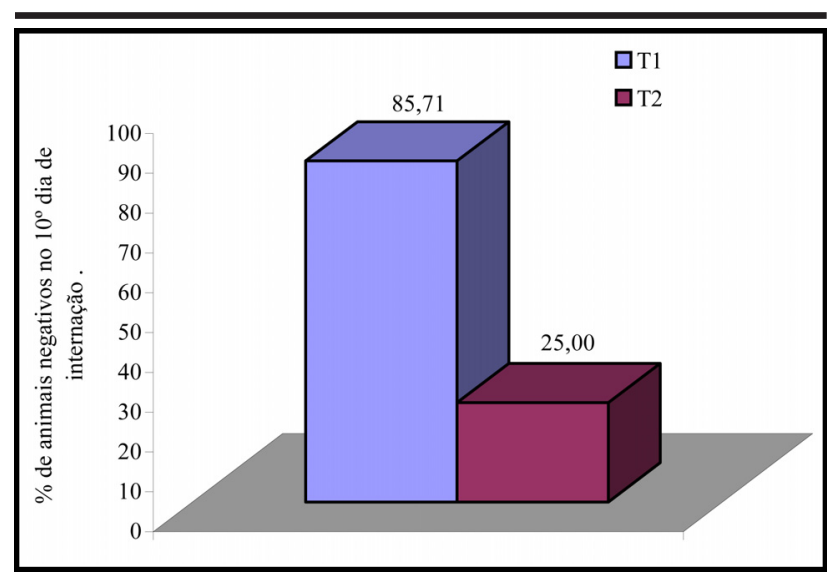

FIGURE 4 - Percentage of animals positive to E.coli in the $1^{\text {st }}$ or $10^{\text {th }}$ day and without the microorganism in the $10^{\text {th }}$ day in the groups T1 (with MOS) and T2 (without MOS).

leukocytes tends to increase, while in a viral infection, drugs, toxic chemicals, toxoplasmosis and Erlichia this number is reduced. Therefore, the results of the present study demonstrate the acute pathogenesis of viral gastroenteritis. No mortality was observed, despite this pathology normally represents the main cause of mortality in small animals. In the Neutrophils analysis, there were no significant 
differences $(\mathrm{P}>0.05)$ in the number of segmented neutrophils between T1 and T2. According to Kantek et al. (1994), neutrophils are the first cells to reach the inflammation foci, identify and neutralize foreign agents, and can be mobilized in large number first from the marginal pool, subsequently from the reserve compartment of the marrow and finally by an increase in the mitotic compartment of the same marrow. The neutrophils are destroyed inside the inflammatory focus, during the phagocytosis of bacteria or other agents (Figure 2). There were no significant differences $(\mathrm{P}>0.05)$ between the two groups with respect to lymphocytes analysis. These data remained on physiological parameters, what can be considered as a clinical improvement. Hematological results showed better homogenization of leukocytes, neutrophils and lymphocytes in animals fed MOS. There was higher instability and a greater variation in the number of evaluated cells in the animals fed diets without MOS, as demonstrated in the graphs (Figure 3). The coproculture results, after the three collections $\left(1^{\text {st }}, 5^{\text {th }}\right.$ and $10^{\text {th }}$ days) in all animals, only enteropathogenic microorganisms were observed and these were positive for:

\section{Pseudomonas aeruginosa}

2. Proteus mirabilis

3. Providencia alcalifaciens

4. Enterobacter cloacae

5. Morganella motganii

6. Citrobacter freundii

7. Escherichia coli

There was a significant difference $(\mathrm{P}<0.05)$ between the groups. Animals fed diets with MOS became negative to pathogenic Escherichia coli while in the animals fed diets without MOS these pathogenic bacteria remained present thus intensifying symptoms of gastroenteritis (figure 4). Bio-Mos was effective in eliminating pathogenic E. coli in $85.71 \%$ of the animals, while in the non-treated group only $25 \%$ were negative to $E$. coli. It can be concluded that Bio-Mos was effective in the control of pathogenic $E$. coli and can be indicated as an adjuvant treatment for gastroenteritis in dogs. There was a significant difference $(\mathrm{P}<0.05)$ between groups $\mathrm{T} 1$ and $\mathrm{T} 2$ regarding the frequency of animals that became negative to E.coli.

\section{Conclusion}

The results of the present study demonstrated that pathogenic bacteria were inactivated in the animals fed diets supplemented with Bio-Mos. Significant differences were observed between the number of dogs fed diets containing MOS that became negative to E.coli and those that were not supplemented with MOS. It can be concluded that BioMos was effective in the control of pathogenic E. coli. Considering the changes in the number of leukocytes, neutrophils and lymphocytes in the animals, further studies evaluating the same parameters must be conducted. The non-supplemented group showed higher variation in the number of leukocytes, neutrophils and lymphocytes, indicating higher instability. Animals fed diets with BioMos remained within normal physiological parameters, what can be considered as a clinical improvement.

\section{References}

1. Sharon N, Lis H. Carbohydrates in cell recognittion. Sci Am. 1993;268:82-9.

2. Mulrennan F. A escolha de uma nova geração. Glicômica Feeding Times. 2003;8(2):5-30

3. Kantek CE, Pachaly JR. Os Leucócitos. In: Manual de Hematologia Veterinária. São Paulo:, Livraria Varela, 1978.

4. Spring P, Wenk C, Dawson KA, Newman KE. The effects of dietary mannanoligosaccharides on cecal parameters and the concentrations of enteric bacteria in the ceca of salmonella-challenged broiler chicks. Poult Sci. 2000;79:205-11.

5. Borges FMO, Nunes IJ. Dietas Específicas para Pacientes Especiais. In: Simpósio de Nutrição de Pets Alltech. Belo Horizonte: Escola de Veterinária-UFMG; 2003, p1-23.

6. Connolly A. Reagindo ao desafio da retirada dos antibióticos promotores de crescimento das rações e a forma como os oligossacarídeos específicos assumiram a dianteira. Feed Compounder. 2001;4:25-6.

7. Swanson KS, Grieshop CM, Flickinger EA, Bauer LL, Chow J, Wolf BW, Garleb KA, Fahey Jr GC. Fructooligosaccharides and Lactobacillus acidophilus modify gut microbial population, total tract nutrient digestibility and fecal protein catabolite concentration in healthy adult dogs. J Nutr 2002;132:3721-31.

8. Grieshop MC. Diet may affect nutrition, immune system of pets. Feedstuffs. 2003;75:26-52.

\section{How to cite this article:}

Gouveia EMF, Silva IS, Van Onselem VJ, Corrêa RAC, Silva CJ. Use of mannanoligosacharides as an adjuvant treatment for gastrointestinal diseases and this effects on E.coli inactivated in dogs. Acta Cir Bras. [serial on the Internet] $2006 ; 21$ Suppl 4. Available from URL: $\underline{\text { http://www.scielo.br/acb. }}$.

* Color figures available from www.scielo.br/acb 